\title{
Hide beetle Dermestes maculatus DeGeer ${ }^{1}$
}

\section{Brianna Shaver and Phillip Kaufman²}

\section{Introduction}

The hide beetle, Dermestes maculatus DeGeer, feeds on carrion and dry animal products. These beetles form aggregations around resources where individuals will feed and mate, attracted by pheromones secreted by males. Aggregations can vary in size, but small sources of food usually have approximately one to 13 beetles (McNamara et al. 2008). The adult beetles have forensic significance in helping to estimate the post mortem interval in suicide or homicide cases (Richardson and Goff 2001). These insects are also pests of the silk industry in Italy and India, and infest stored animal products such as dried fish, cheese, bacon, dog treats, and poultry (Veer et al. 1996, Cloud and Collinson 1986). Another beetle of both forensic and economic importance in the Dermestidae is Dermestes lardarius. This beetle can be distinguished from Dermestes maculatus as it has a yellow band of hairs on the top half of each elytron (Gennard 2007).

\section{Synonymy}

Dermestes maculatus DeGeer, 1774

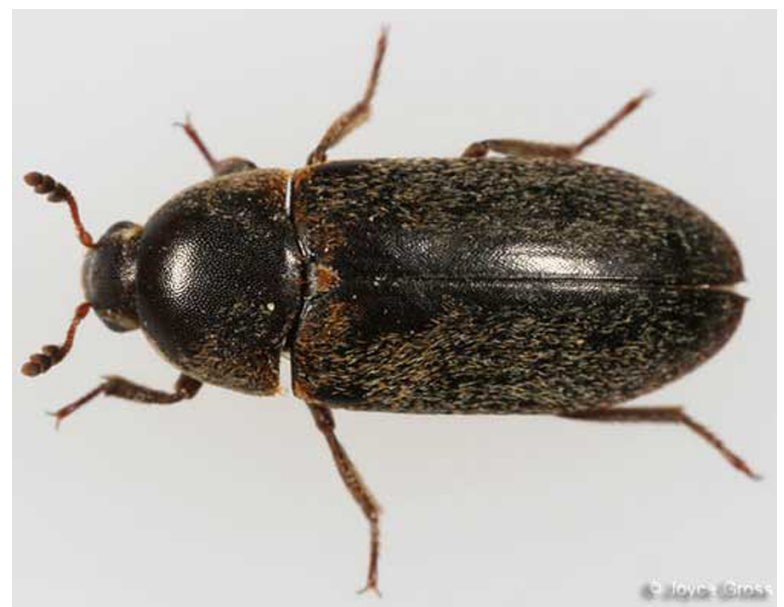

Figure 1. Dorsal view of an adult hide beetle, Dermestes maculatus DeGeer. Photograph by: Joyce Gross, University of California - Berkeley

Dermestes vulpinus Fabricius, 1781

Dermestes marginatus Thunberg, 1781

Dermestes senex Germar, 1824

Dermestes lateralis Sturm, 1826

Dermestes elongatus Hope, 1834

Dermestes lupinus Erichson, 1843

1. This document is EENY-466, one of the Featured Creatures series of the Entomology and Nematology Department, Cooperative Extension Service, Institute of Food and Agricultural Sciences, University of Florida. Published: November 2009. This document is also available on Featured Creatures website at http://entomology.ifas.ufl.edu/creatures. Please visit the EDIS website at http://edis.ifas.ufl.edu. Additional information on these organisms, including many color photographs, is available at the Entomology and Nematology Department website at http://entnemdept.ifas.ufl.edu/. 2. Brianna Shaver and Phillip Kaufman, Department of Entomology and Nematology, University of Florida, Gainesville, FL

The Institute of Food and Agricultural Sciences (IFAS) is an Equal Opportunity Institution authorized to provide research, educational information and other services only to individuals and institutions that function with non-discrimination with respect to race, creed, color, religion, age, disability, sex, sexual orientation, marital status, national origin, political opinions or affiliations. U.S. Department of Agriculture, Cooperative Extension Service, University of Florida, IFAS, Florida A. \& M. University Cooperative Extension Program, and Boards of County Commissioners Cooperating. Millie Ferrer-Chancy, Interim Dean 
Dermestes semistriatus Boheman, 1851

Dermestes rattulus Mulsant and Rey, 1868

Dermestes sudanicus Gredler, 1877

Dermestes truncatus Casey, 1916

(From ITIS 2009, Hinton 1945)

\section{Distribution}

Dermestes maculatus is native throughout the continental United States and Canada, and also Hawaii. It is also known to occur in Oceania, southeast Asia, and Italy (Integrated Taxonomic Information System 2009, Veer et al. 1996).

\section{Description}

Eggs: Dermestes maculatus eggs are typically laid in batches of three to 20 . The amount of eggs a single female can lay over a lifetime varies greatly, ranging from 198 to 845 (Hinton 1945).

Larvae: The bodies of the larvae are covered in rows of hairs of different lengths, called setae. The underside of the abdomen is typically

yellowish-brown while the dorsal surface is typically dark brown, usually with a central yellow line. Two long horn-like protrusions are located on the upper surface of the last segment, partially hidden by surrounding hairs (Haines and Rees 1989). The protrusions, called urogomphi, curve upward and away from the tip of the abdomen. This distinguishes the larvae from larvae of $D$. lardarius, which has the urogomphi curving downward toward the tip of the abdomen (Hedges and Lacey 1996).

Pupae: The last larval skin will usually provide a protective covering for the pupa. The end of the pupal chamber toward the surface can be closed by either debris from the substance which the larvae bore into or from the last larval skin (Hinton 1945). The pupae are an oval shape, usually smaller than the larvae, and do not have the many long hair-like projections (Kulshrestha and Satpathy 2001).

Adults: Dermestes maculatus adults range in size from 5.5 to $10.0 \mathrm{~mm}$. Each side of the thorax has a band of white hairs. The underside of the abdomen is

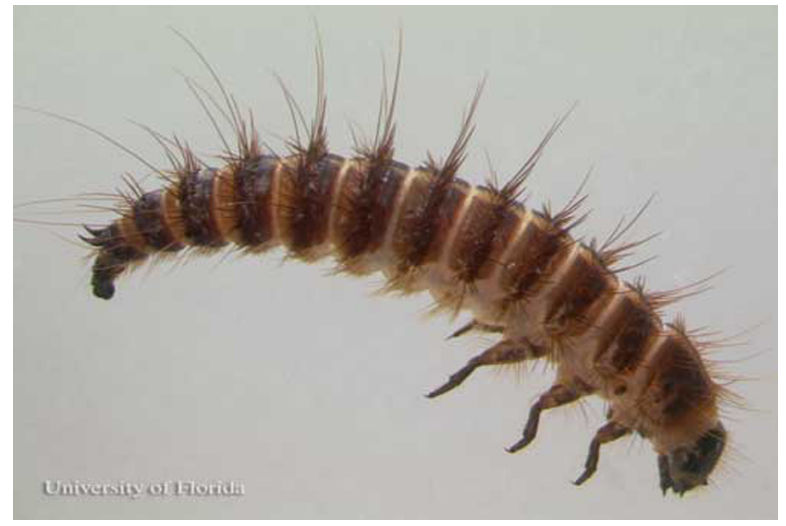

Figure 2. Larva of the hide beetle, Dermestes maculatus DeGeer. Photograph by: Lyle J. Buss and Brianna Shaver, University of Florida

primarily white with black spots at the sides, and a large black patch on the last segment. The elytra are dark brown or black, with hairs that are mostly black, yellow, or white. The antennae are short and segmented with a club at the tip. The edges of the abdominal end of the elytra are serrated and end in a small spine projecting straight out (Haines and Rees 1989, Hinton 1945).

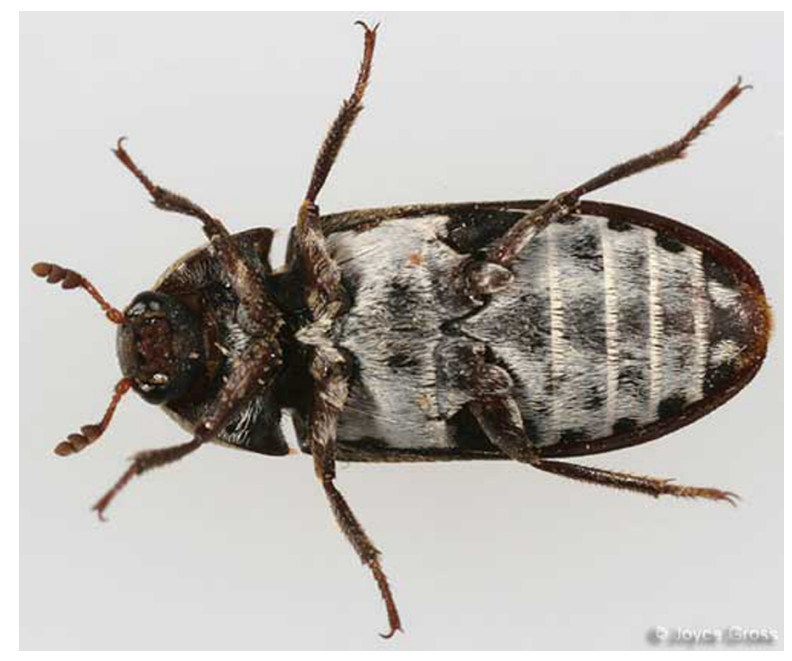

Figure 3. Ventral view of an adult hide beetle, Dermestes maculatus DeGeer. Photograph by: Joyce Gross, University of California - Berkeley

Frass: Frass, or feces, from D. maculatus appear dark brown, fibrous, and resemble horse hair. Evidence of frass can indicate the past presence of beetles (Schroeder et al. 2002). 


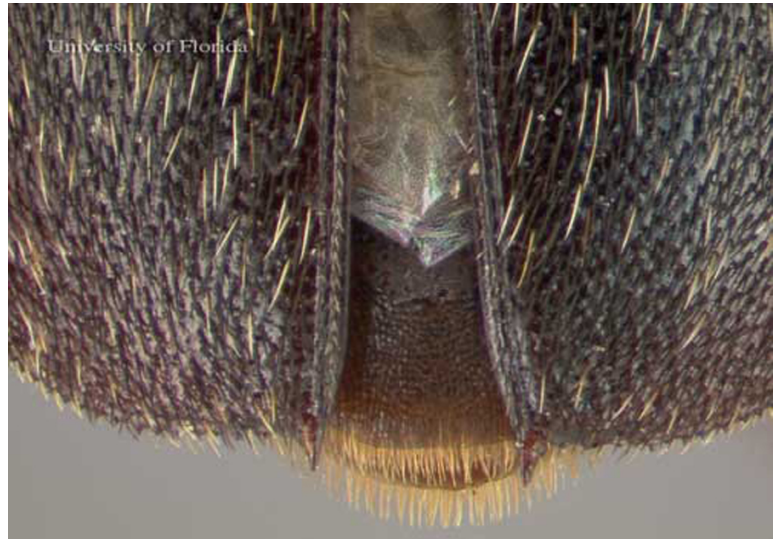

Figure 4. Distal portion of the elytra of the adult hide beetle, Dermestes maculatus DeGeer. Notice the serrations on the distal edge of the elytra with each elytra ending in a point. Photograph by: Lyle J. Buss and Brianna Shaver, University of Florida

\section{Life Cycle and Biology}

The life cycle of $D$. maculatus on either a carcass in dry-decay or in stored animal products requires approximately five to seven weeks to complete under optimum conditions. The adults consume the remains of the carcass or the animal product (Archer and Elgar 1998, Haines and Rees 1989). Pheromones, secreted by males through a gland on the base of the abdomen, are used to attract females. Males and females will mate multiple times and the female will lay eggs within 24 hours of the first mating (Jones et al. 2006). Eggs are laid in cracks of the matter on which they are feeding (Haines and Rees 1989). Females are capable of laying eggs continuously (Jones et al. 2006).

Larvae will pass through five to 11 instars, the number of instars increasing with unfavorable conditions (Haines and Rees 1989, Hinton 1945). During the last 10 days of the final instar, the larvae will seek out a place to pupate, typically within the meat or a non-food substance such as wood. Exposed pupae that have failed to find a suitable pupal chamber are often cannibalized by larvae. Larvae without a suitable place to pupate can delay pupation by over 20 days, but at the cost of lower adult body mass and increased risk to fatal disease (Archer and Elgar 1998). Survivorship for individuals is the highest between $25^{\circ} \mathrm{C}$ and $30^{\circ} \mathrm{C}$ (Richardson and Goff 2001).
Once adults, the beetles can disperse to other food sources by flying (Haines and Rees 1989). Adult beetles typically live between four to six months.

\section{Forensic Importance}

The appearance of $D$. maculatus on decomposing remains of human and other animals makes it a candidate insect to estimate postmortem interval in cases of suicide, homicide, or unattended death. Adults generally arrive five to 11 days following death (Richardson and Goff 2001). This beetle becomes one of the dominant insects present in mid to late decay. Larvae of $D$. maculatus have been collected as late as day 51 following death (Richardson and Goff 2001). While the adults have been detected at early stages of decay, the larvae are the life stage used for post-mortem interval estimation. Larvae do not appear on corpses until the later stages of decay when the body has dried out. Full development of $D$. maculatus is only reached when temperatures are consistently above $18^{\circ} \mathrm{C}$, and will take 96 days at $18^{\circ} \mathrm{C}$ from the time the egg is laid to reach adulthood (Arnaldos et al. 2004). The optimum temperature for $D$. maculatus development is approximately $30^{\circ} \mathrm{C}$, where the beetles reach adulthood around 38 days (Richardson and Goff 2001).

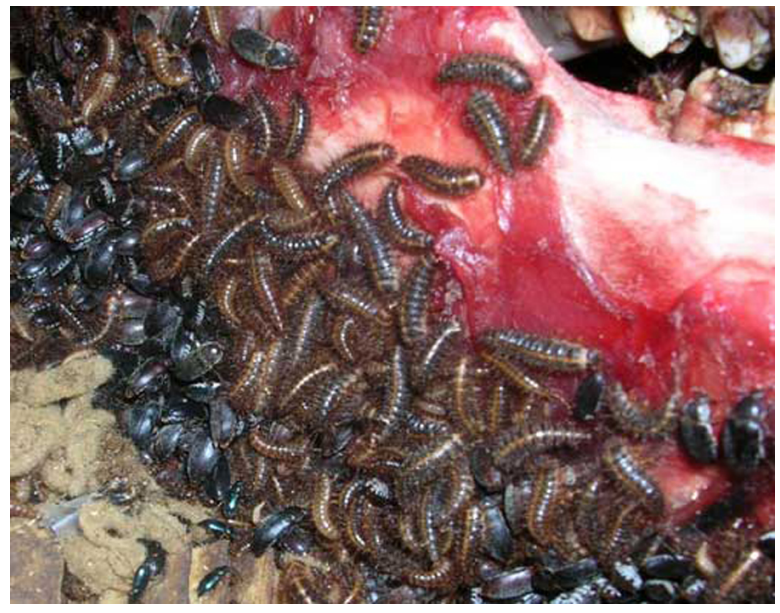

Figure 5. Larvae and adults of the hide beetle, Dermestes maculatus DeGeer, consume flesh and hide on an animal skull. Photograph by: Troy Roper

The presence of these beetles can be detected through identification of their feces, which appears dark brown and stringy. Evidence of these beetles may also be indicated by round-edged bite marks on 
furniture as well as the corpse. The hotter and drier the conditions the corpse is kept in limits fly larvae development on the corpse, as they need softer material to eat. These conditions are more favorable to the hide beetles such as D. maculatus (Schroeder et al. 2002).

In a study done in Thailand involving 30 cadavers, D. maculatus was only collected from bodies that had been deposited in forested areas, as opposed to outdoor and indoor urban or suburban areas (Sukontason et al. 2007). It was also noted that this beetle was not present on pig carcasses studied in China during the winter season, but present during other seasons (Wang et al. 2008).

Due to their ability to clear skin and hair off bodies cleanly, D. maculatus can be used to clean bones to assist with forensic cases. Cleaned bones can offer evidence of demographical information, such as age and gender, or evidence of trauma, and possibly marks left in the bone by knives or saws. The beetles are particularly useful for small, delicate bones, which may be harmed by chemical means of cleaning bone. Progress needs to be monitored, however, as the beetles may begin to consume bone if left without other sources of food for too long (Mairs et al. 2004).

\section{Economic Importance}

Today, D. maculatus is a minor pest of the silk industry, though in the past it has been a major problem. In 1987 in India, a 20\% loss was recorded in silk production due to the beetle. The primary cause of loss was due to the feeding of $D$. maculatus larvae boring into the cocoons to eat the silkworm pupae, and thus the cocoons could not be used for reeling. In 1931 in Italy, the beetle was also reported to be a vector for pebrine disease, a disease that has previously caused the closure of the silkworm industry in many countries (Veer et al. 1996). Other commodities that $D$. maculatus can damage include stored animal products such as dried fish, cheese, hide, fur, bacon, and dog treats. The larvae can cause considerable damage to timber, cork, plaster, linen, and cotton when they bore into these materials to pupate (Veer et al. 1996). This structural damage is also a problem in poultry industry, particularly in cage-layered facilities, in addition to the adults feeding off broken eggs and small animal carcasses (Cloud and Collison 1986). Bone cleaning by $D$. maculatus is also used by taxidermists to clean skulls or by museums to clean bone specimens (Mairs et al. 2004).

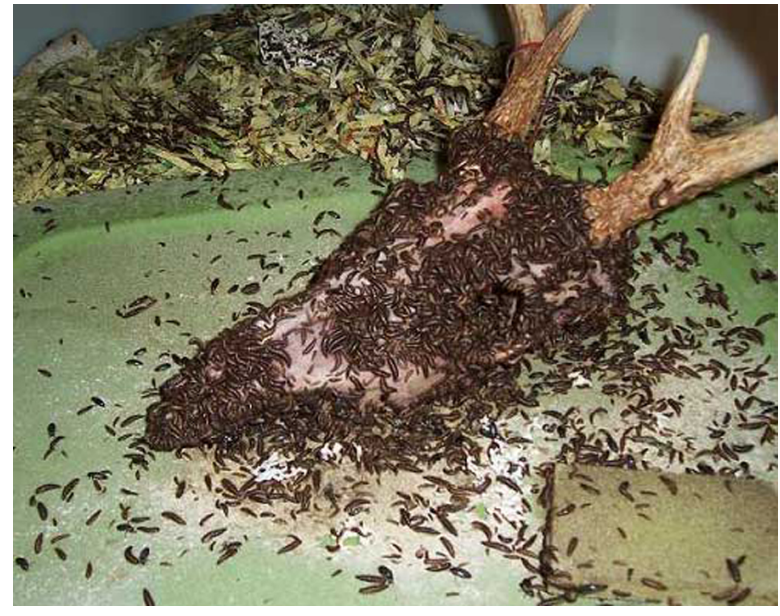

Figure 6. Larvae of the hide beetle, Dermestes maculatus DeGeer, cleaning the skull of a white tailed deer. Photograph by: Josh Watts, www.wattsskulls.com

\section{Selected References}

Archer MS, Elgar MA. 1998. Cannibalism and delayed pupation in hide beetles, Dermestes maculatus DeGeer (Coleoptera: Dermestidae). Australian Journal of Entomology 37: 158-161.

Arnaldos MI, Sanchez F, Alvarez P, Garcia MD. 2004. A forensic entomology case from the southeastern Iberian Peninsula. Aggrawal's Internet Journal of Forensic Medicine and Toxicology 5: 22-25.

Cloud JA, Collison CH. 1986. Comparison of various poultry house litter components for hide beetle (Dermestes maculatus DeGeer) larval development in the laboratory. Poultry Science 65: 1911-1914.

Gennard DE. 2007. Forensic Entomology. John Wiley and Sons Ltd., England. pp. 64-66.

Haines CP, Rees DP. (1989). Dermestes spp. A Field Guide to the Types of Insects and Mites Infesting Cured Fish. http://www.fao.org/docrep/003/t0146e/T0146E04.htm (28 September 2009). 
Hedges SA, Lacey MS. 1996. Pest Control

Technology Field Guide for the Management of Structure-infesting Beetles. Franzak and Foster Co., Cleveland, OH. 95 pp.

Hinton HE. 1945. A Monograph of the Beetles Associated with Stored Products, Volume I. British Museum (Natural History), England. pp. 261-268.

ITIS. (September 2009). Dermestes maculatus De Geer, 1774, Taxonomic Serial No.: 114980.

Integrated Taxonomic Information System. http://www.itis.gov/servlet/SingleRpt/

SingleRpt?search_topic $=$ TSN\&search_value $=114980$ (28 September 2009).

Jones TM, McNamara KB, Colvin PGR, Featherston R, Elgar MA. 2006. Mating frequency, fecundity and fertilization success in the hide beetle, Dermestes maculatus. Journal of Insect Behavior 19: 357-371.

Kulshrestha P, Satpathy DK. 2001. Use of beetles in forensic entomology. Forensic Science International 120: $15-17$.

Mairs S, Swift B, Rutty GN. 2004. Detergent: an alternative approach to traditional bone cleaning methods for forensic practice. The American Journal of Forensic Medicine and Pathology 25: 276-284.

McNamara KB, Brown RL, Elgar MA, Jones TM. 2008. Paternity costs from polyandry compensated by increased fecundity in the hide beetle. Behavioral Ecology 19: 433-440.

Richardson MS, Goff ML. 2001. Effects of temperature and intraspecific interaction on the development of Dermestes maculatus (Coleoptera: Dermestidae). Journal of Medical Entomology 38 : 347-351.

Schroeder H, Klotzbach H, Oesterhelweg L, Püschel K. 2002. Larder beetles (Coleoptera: Dermestidae) as an accelerating factor for decomposition of a human corpse. Forensic Science International 127: 231-236.

Sukontason K, Narongchai P, Kanchai C, Vichairat K, Sribanditmongkol P, Bhoopat T, Kurahashi H, Chockjamsai M, Piangjai S, Bunchu N, Vongvivach S, Samai W, Chaiwong T, Methanitikorn R, Ngern-Klun R, Sripakdee D, Boonsriwong W,
Siriwattanarungsee S, Srimuangwong C, Hanterdsith B, Chaiwant K, Srisuwan C, Upakut S, Moopayak K, Vogtsberger RC, Olson JK, Sukontason KL. 2007. Forensic entomology cases in Thailand: a review of cases from 2000 to 2006. Parisitology Research 101: 1417-1423.

Veer V, Negi BK, Rao KM. 1996. Dermestid beetles and some other insect pests associated with stored silkworm cocoons in India, including a world list of dermestid species found attacking this commodity. Journal of Stored Products Research 32: 69-89.

Wang J, Li Z, Chen Y, Chen Q, Yin X. 2008. The succession and development of insects on pig carcasses and their significances in estimating PMI in south China. Forensic Science International 179: 11-18. 